\title{
Miervaldis Kaminskis, medicīnas doktors
}

(1922-2011)

Miervaldis Kaminskis dzimis 1922. gada 19. decembrī Madonas apriņ̧̧̧a Praulienas pagastā. Pēc Rēzeknes Valsts skolotāju institūta beigšanas viņš 1946. gadā iestājās Latvijas Valsts universitātes (LVU) Medicīnas fakultātē. Jau pirmajā studiju gadā topošo ārstu saistīja anatomija, viṇa uztverē anatomija ir visnozīmīgākais priekšmets medicīnas apguvei, visu pārējo priekšmetu atslēga. Tā, būdams vēl students, Miervaldis Kaminskis pievērsās anatomijai. Tāpēc nav brīnums, ka pēdējos studiju gados viņšs jau bija Anatomijas katedras darbinieks, kura uzdevumos ietilpa ne tikai mācību preparātu gatavošana, bet arī subasistenta pienākumi. 1952. gadā Miervaldis Kaminskis beidza Rīgas Medicīnas institūtu (RMI). Ārsta diploms nemainīja iesākto docētāja darbu Anatomijas katedrā, bet vēl pievienojās daudzi sabiedriskie pienākumi. Viņš vienmēr bija studentu mīlēts, taisnīgs un gudrs docētājs, kura atbalstu studenti juta vajadzīgajā brīd̄̄. Tādēl daudzi RMI beigušie ārsti nezaudēja saikni ar savu skolotāju Miervaldi Kaminski arī visa sava darba mūža garumā.

Miervaldis Kaminskis bija vien̄̄gais Anatomijas katedras docētājs, kuram bija arī augstākā pedagoǵiskā izglītība. Viņš lieliski prata izmantot savas pedagoǵiskās zināšanas, lai studentiem atvieglotu daudzo anatomisko terminu iegaumēšanu, stāstīja, ka nav jēgas mehāniski uzkrāt zināšanas, ja trūkst prasmes un izpratnes, kā tās izmantot savā praktiskajā darbā.

Lai arī ikdienas darbā ļoti noslogots, Miervaldis Kaminskis lēni, bet neatlaidīgi un rūpīgi veica zinātniskos pētījumus un publicēja to rezultātus, piedalījās Latvijas Anatomu, histologu un embriologu zinātniskās biedrības sēdēs un konferencēs gan Latvijā, gan arī ārpus tās. Viņa disertācijas darba tēma bija "Krūškurvja priekšèjās un mugurējās sienas vēnu morfoloǵija un topogrāfija”, disertāciju viņš aizstāvēja 1971. gadā, iegūstot 
medicīnas zinātṇu kandidāta (vēlāk - medicīnas zinātñu doktora) grādu. Pagājušā gadsimta piecdesmitajos gados strauji attīstījās krūškurvja ķirurǵija, tādēḷ Miervalža Kaminska disertācijas tēma bija aktuāla arī praktiskās medicīnas jomā. Disertācijā pētīta ontoǵenētiskā aspektā vēnu un to vārstuḷu veidošanās cilvēkiem, izmantojot gan cilvēka augḷu $(15-52 \mathrm{~cm})$, gan 14-83 gadu vecu cilvēku sekciju materiālu. Miervalža Kaminska darbu augstu novērtēja disertācijas oponents profesors Aleksandrs Bieziņš.

Miervaldis Kaminskis par medicīnu ieinteresēja arī savas meitas: viena kḷuva par stomatolog̣i, bet otra turpina tēva iesāktās anatomijas docētāja tradīcijas. Tagad Miervalža Kaminska meita - medicīnas doktore profesore Gundega Knipše - ir Latvijas Universitātes (LU) Medicīnas fakultātes Anatomijas un histolog̣ijas katedras vadītāja. 2008. gadā LU apgāds laida klajā Gundegas Knipšes redakcijā sagatavotu mācību grāmatu "Cilvēka anatomija. Roka. Kāja”, kur autoru sarakstā ir minēts arī Miervaldis Kaminskis.

Miervaldis Kaminskis miris 2011. gada 22. jūnijā Rīgā.

\section{Aina Dālmane,}

Dr. habil. med. 